\title{
DIVERSITY OF CRYPHONECTRIA PARASITICA POPULATIONS FROM THE CARPATHIAN BASIN
}

\author{
GÁBOR GÖRCSÖS ${ }^{1}$, LÁSZLÓ IRINYI ${ }^{1 \neq}$, LÁSZLÓ RADÓCZ ${ }^{1}$, \\ GÁBOR TARCALI ${ }^{1}$ and ERZSÉBET SÁNDOR ${ }^{2 *}$ \\ ${ }^{1}$ Faculty of Agricultural and Food Sciences and Environmental Management, \\ Institute of Plant Protection, University of Debrecen, Debrecen, Hungary \\ ${ }^{2}$ Faculty of Agricultural and Food Sciences and Environmental Management \\ Institute of Food Science, University of Debrecen, Debrecen, Hungary \\ 'Present address: Molecular Mycology Research Laboratory, \\ Centre for Infectious Diseases and Microbiology, University of Sydney, \\ Westmead Millennium Institute for Medical Research, Sydney, Australia
}

(Received: 14 January 2015; accepted: 16 April 2015)

The ascomycetous fungus Cryphonectria parasitica (Murr.) is one of the most important fungal pathogens of chestnut (Castanea sativa Mill.), causing chestnut blight. It is originated from Eastern Asia and was introduced into North America, and later into Europe. Almost 100 C. parasitica isolates were collected mainly from the Carpathian Basin to study their diversity and phylogenetic relationships. Three nuclear molecular markers were tested: (i) internal transcribed spacers (ITS), (ii) translation elongation factor 1 subunit alpha (tefl), and (iii) six microsatellite loci. The ITS region proved to be highly polymorphic but this kind of variability did not reflect the geographical regions of the isolates, while the tefl sequences were identical in all isolates. Microsatellite haplotype diversity was relatively high (0.923-0.984) calculated for the fungal populations of the Carpathian Basin. This may have resulted from the multiple introductions from diverse origins of the populations, close to the first site of observation in Northern Italy. The BAPS analysis of the microsatellite markers occasionally grouped together samples from remote geographical origin, suggesting human assistance in the introduction of new C. parasitica haplotypes from distinct areas.

Keywords: Cryphonectria parasitica, population structure, phylogenic markers, microsatellite, BAPS analysis

\section{Introduction}

The causal agent of chestnut blight, a heterothallic ascomycetous fungus, Cryphonectria parasitica (Murr.) Barr (syn. Endothia parasitica [Murr.] And.) is

*Corresponding author; E-mail: karaffa@agr.unideb.hu 
one of the most important fungal pathogens of chestnut (Castanea sativa Mill.) in Europe and North America. It originated from Eastern Asia and was introduced into North America at the beginning of the $20^{\text {th }}$ century where it devastated the American chestnut (Castanea dentata, Fagaceae, Fagales) causing serious damage in orchards and in forests [1]. In the middle of the last century, the pathogen was introduced into Europe, firstly reported in Italy [2] and has infested the European chestnut (Castanea sativa Mill) populations. In Central Europe, the pathogen was firstly identified in Austria by Donaubauer [3]. In Hungary, the first symptoms of the disease were reported by Körtvély in 1969 [4], then in Slovakia by Juhásová [5], in Romania by Florea and Popa [6] and in Ukraine by Radócz [7]. Nowadays the chestnut blight became an important and widespread disease in Hungary. The disease kills the infected tree branches and causes a rapid death of the entire tree resulting in environmental and economic concerns.

In this study, we investigated phylogenetic relationships of $C$. parasitica isolates collected from different European growing sites mainly from the Carpathian Basin.

Many studies using different molecular markers and other traits such as vegetative compatibility were published to assess population genetic parameters and genetic diversity among isolates from different geographical regions [8-15]. Translation elongation factor 1 subunit alpha $(\mathrm{EF} 1 \alpha)$ is part of the cytosolic EF1 complex, whose primary function is to promote the binding of aminoacyl-tRNA to the ribosome in a GTP-dependent process [16]. Its coding gene, tefl is well suited for determining phylogenetic relationships [17], due to its universal occurrence and its presence as a single copy within the genome [18]. It has been proven to be a useful gene to resolve phylogenetic relationships at species level as well as in deeper divergences where amino acid substitutions provide phylogenetic resolution. Here, we used a primer pair which facilitates the PCR amplification of the large intron of tefl gene [19]. So far, the translation elongation factor has not been used to investigate phylogenetic relationships among $C$. parasitica.

Ribosomal DNA (rDNA) has long been used as a potential marker for phylogenetic studies (reviewed by Avise, [20]). The rRNA genes are organized in clusters of tandemly repeated units, each of which consists of coding regions (18S, 5.8S, and 28S) [21] and 2 internal transcribed spacers (ITS) and intergenic spacer (formerly called the "Non-Transcibed Spacer", NTS) region. While the coding regions are evolutionarily conserved and have been utilized for phylogenetic inferences for major phyla (reviewed by Hillis and Dixon [22]), the two ITS regions are appropriate for detecting differences between co-specific individuals and are hence potentially useful markers to study the relationships of populations and closely related species in fungal, plant, and animal taxa due to their relatively rapid evolutionary rates [23-29]. In this study, we used the complete inter- 
nal transcribed spacer regions since many studies were published using ITS sequences for phylogenetic analysis in the Cryphonectria genus [30, 31].

Microsatellite loci, also called simple sequence repeats (SSR), are widely used as genetic markers because of their ubiquity, ease to score, co-dominance, reproducibility, assumed neutrality and high level of polymorphism [32]. Microsatellites are tandemly repeated specific DNA sequences of 1 to 10 bases up to about 100 times [33]. The lengths of microsatellites tend to be highly polymorphic between individuals due to variation in the number of repeat units of different alleles. Like all genetic loci, SSRs are subject to point mutations but slippedstrand mispairing at meiosis or during DNA replication also may occur and can change the number of repeat units [34, 35]. Microsatellites are powerful markers for genetics and population biology analyses because they have co-dominant alleles and are amplified by specific primers. They are more polymorphic than other amplifiable markers [36]. Their mutation rates are thought to vary from $10^{6}$ to $10^{3}$ per locus per gamete per generation depending on organism and locus [37, 38]. Microsatellites have been evaluated extensively in many fields of biology including the population genetic studies of $C$. parasitica. Breuillin et al. [10] identified high genetic diversity in $C$. parasitica populations of different geographical regions of France using microsatellite loci. Kubisiak et al. [39] reported 53 polymorphic microsatellite loci for population genetic studies of C. parasitica. Other studies used different molecular methods such as DNA fingerprinting and RFLP for genetic population studies mostly to retrace the C. parasitica's history of invasion into North America and Europe during the twentieth century $[9,40,41]$.

\section{Materials and Methods}

\section{Isolates}

Almost 100 C. parasitica isolates were studied from different parts of European countries but mainly from the Middle-Europe and the Carpathian Basin (Table I and Fig. 1). Bark samples were collected from chestnut trees located in geographically different areas. In each site, bark samples were collected from the margin of cankers from at least 10 evenly distributed, blighted trunks. Only one bark sample was collected from each trunk to avoid sampling clones. Individual samples were surface disinfected in $70 \%$ ethanol, rinsed in sterile water then placed on PDA (40 g potato dextrose agar, Scharlau, in 11 distilled water). Plates were incubated at $24^{\circ} \mathrm{C}$ in the dark for 7 days and all cultures were checked for typical $C$. parasitica characteristics. 
Table I. Origin of Cryphonectria parasitica isolates

\begin{tabular}{|c|c|c|c|c|c|c|c|}
\hline \multirow{2}{*}{$\begin{array}{l}\text { Sample } \\
\text { name }^{1}\end{array}$} & \multirow{2}{*}{ Location $^{2}$} & \multirow{2}{*}{ Country } & \multirow{2}{*}{$\begin{array}{l}\text { Collection } \\
\text { date }^{2}\end{array}$} & \multirow{2}{*}{$\begin{array}{l}\text { Population } \\
\text { ID }^{3}\end{array}$} & \multirow{2}{*}{$\begin{array}{l}\text { BAPS } \\
\text { Group }^{4}\end{array}$} & \multicolumn{2}{|c|}{ Accession number of } \\
\hline & & & & & & tef1 & ITS \\
\hline AGF 2 & Ágfalva & Hungary & 9 May 2012 & 1 & 1 & & KC844291 \\
\hline AGF 4 & Ágfalva & Hungary & 9 May 2012 & 1 & 1 & & KC844292 \\
\hline DOBR 1 & Döbröce & Hungary & 10 May 2012 & 1 & 1 & KC879169 & КC844303 \\
\hline DOBR 3 & Döbröce & Hungary & 10 May 2012 & 1 & 1 & KC879170 & KC844304 \\
\hline DOBR 5 & Döbröce & Hungary & 10 May 2012 & 1 & 1 & KC879171 & KC 844305 \\
\hline IHB 1 & Iharosberény & Hungary & 10 May 2012 & 1 & 1 & & \\
\hline IHB 3 & Iharosberény & Hungary & 10 May 2012 & 1 & 1 & & \\
\hline KAD 1 & Kadarkút & Hungary & 7 August 2012 & 1 & 1 & KC879176 & \\
\hline KAD 3 & Kadarkút & Hungary & 7 August 2012 & 1 & 1 & KC879177 & \\
\hline PÉCS 1 & Pécs & Hungary & 22 September 2012 & 1 & 2 & KC879194 & KC844335 \\
\hline PÉCS 3 & Pécs & Hungary & 22 September 2012 & 1 & 2 & KC879195 & KC844336 \\
\hline BF 1 & Sopron & Hungary & 9 May 2012 & 1 & 1 & & KC844316 \\
\hline BF 3 & Sopron & Hungary & 9 May 2012 & 1 & 1 & & KC844317 \\
\hline FBR 1 & Sopron & Hungary & 9 May 2012 & 1 & 1 & & KC844310 \\
\hline FBR 3 & Sopron & Hungary & 9 May 2012 & 1 & 1 & & KC844311 \\
\hline PRINC 1 & Sopron & Hungary & 9 May 2012 & 1 & 1 & & KC 844341 \\
\hline PRINC 3 & Sopron & Hungary & 9 May 2012 & 1 & 1 & & KC844342 \\
\hline ZENG 2 & Zengővárkony & Hungary & 22 September 2012 & 1 & 4 & КC879218 & \\
\hline ZENG 3 & Zengővárkony & Hungary & 22 September 2012 & 1 & 4 & KC879219 & \\
\hline BRAT 1 & Bratislava & Slovakia & 18 January 2012 & 1 & 6 & KC879166 & KC844300 \\
\hline BRAT 3 & Bratislava & Slovakia & 18 January 2012 & 1 & 6 & KC879167 & KC844301 \\
\hline MOD 1 & Modra & Slovakia & 18 January 2012 & 1 & 3 & & KC844324 \\
\hline MOD 4 & Modra & Slovakia & 18 January 2012 & 1 & 3 & KC879183 & KC844325 \\
\hline PAR 1 & Párovské Háje & Slovakia & 18 January 2012 & 1 & 9 & KC879191 & KC844332 \\
\hline PAR 3 & Párovské Háje & Slovakia & 18 January 2012 & 1 & 9 & KC879192 & KC844333 \\
\hline PAR 5 & Párovské Háje & Slovakia & 18 January 2012 & 1 & 9 & KC879193 & KC844334 \\
\hline SVE 1 & Svätý Jur & Slovakia & 18 January 2012 & 1 & 5 & & КC844347 \\
\hline SVE 3 & Svätý Jur & Slovakia & 18 January 2012 & 1 & 5 & & KC844348 \\
\hline ÉRSEK 1 & Érsekvadkert & Hungary & 13 May 2011 & 2 & 6 & KC879173 & KC844307 \\
\hline ÉRSEK 3 & Érsekvadkert & Hungary & 13 May 2011 & 2 & 6 & KC879174 & КC844308 \\
\hline B 1 & Nagymaros & Hungary & 13 May 2011 & 2 & 7 & КC844290 & KC 800708 \\
\hline
\end{tabular}


Table I. (cont.)

\begin{tabular}{|c|c|c|c|c|c|c|c|}
\hline \multirow{2}{*}{$\begin{array}{l}\text { Sample } \\
\text { name }\end{array}$} & \multirow{2}{*}{ Location $^{2}$} & \multirow{2}{*}{ Country } & \multirow{2}{*}{$\begin{array}{l}\text { Collection } \\
\text { date }^{2}\end{array}$} & \multirow{2}{*}{$\begin{array}{l}\text { Population } \\
\text { ID }^{3}\end{array}$} & \multirow{2}{*}{$\begin{array}{l}\text { BAPS } \\
\text { Group }^{4}\end{array}$} & \multicolumn{2}{|c|}{ Accession number of } \\
\hline & & & & & & tef1 & ITS \\
\hline C 1 & Nagymaros & Hungary & 13 May 2011 & 2 & 7 & KC879168 & KC844302 \\
\hline E 3 & Nagymaros & Hungary & 13 May 2011 & 2 & 7 & KC879172 & KC844306 \\
\hline F 4 & Nagymaros & Hungary & 13 May 2011 & 2 & 7 & & KC844309 \\
\hline $\mathrm{J} 2$ & Nagymaros & Hungary & 13 May 2011 & 2 & 7 & KC879175 & KC844314 \\
\hline MV $1 / 4$ & Nagymaros & Hungary & 13 May 2011 & 2 & 7 & KC879184 & KC851950 \\
\hline MV 1/6 & Nagymaros & Hungary & 13 May 2011 & 2 & 7 & KC879185 & KC851951 \\
\hline N 2 & Nagymaros & Hungary & 13 May 2011 & 2 & 7 & KC879186 & KC844315 \\
\hline KRNA 1 & Krná & Slovakia & 3 August 2012 & 2 & 8 & & \\
\hline KRNA 5 & Krná & Slovakia & 3 August 2012 & 2 & 8 & & \\
\hline MDK 1 & Modrý Kameň & Slovakia & 8 December 2011 & 2 & 8 & & KC844320 \\
\hline MDK 2 & Modrý Kameň & Slovakia & 8 December 2011 & 2 & 8 & & KC844321 \\
\hline MDK 4 & Modrý Kameň & Slovakia & 8 December 2011 & 2 & 8 & KC879180 & KC844322 \\
\hline MDK 6 & Modrý Kameň & Slovakia & 8 December 2011 & 2 & 8 & & KC844323 \\
\hline PAL 2 & Pálháza & Hungary & 18 May 2012 & 3 & 1 & & KC844330 \\
\hline PAL 3 & Pálháza & Hungary & 18 May 2012 & 3 & 1 & & KC844331 \\
\hline PETROVCE 1 & Petrovce & Slovakia & 19 September 2012 & 3 & 9 & KC879198 & KC844339 \\
\hline PETROVCE 3 & Petrovce & Slovakia & 19 September 2012 & 3 & 9 & KC879199 & KC844340 \\
\hline BOB 1-1 & Bobovyshche & Ukraine & 23 April 2011 & 3 & 10 & KC851936 & KC844294 \\
\hline BOB 1-3 & Bobovyshche & Ukraine & 23 April 2011 & 3 & 10 & КC879161 & KC844295 \\
\hline BOB 2-2T & Bobovyshche & Ukraine & 23 April 2011 & 3 & 10 & KC879162 & KC844296 \\
\hline BOB 2-4T & Bobovyshche & Ukraine & 23 April 2011 & 3 & 10 & KC879163 & KC844297 \\
\hline BOB 3-1 & Bobovyshche & Ukraine & 23 April 2011 & 3 & 10 & KC879164 & KC844298 \\
\hline BOB 3-3 & Bobovyshche & Ukraine & 23 April 2011 & 3 & 10 & KC879165 & KC844299 \\
\hline RO 4 & Rostovjatica & Ukraine & 23 April 2011 & 3 & 14 & KC879203 & KC844345 \\
\hline RO 6 & Rostovjatica & Ukraine & 23 April 2011 & 3 & 14 & KC879204 & KC844346 \\
\hline SER 1 & Serednje & Ukraine & 23 April 2011 & 3 & 11 & KC879220 & \\
\hline SER 3 & Serednje & Ukraine & 23 April 2011 & 3 & 11 & KC879221 & \\
\hline FEL 1T & Nagybánya & Romania & 7 September 2011 & 4 & 12 & & KC844312 \\
\hline FEL 4 & Nagybánya & Romania & 7 September 2011 & 4 & 12 & & KC844313 \\
\hline KOBA 2 & Nagybánya & Romania & 7 September 2011 & 4 & 12 & KC879178 & KC 844318 \\
\hline KOBA 4T & Nagybánya & Romania & 7 September 2011 & 4 & 12 & KC879179 & KC844319 \\
\hline
\end{tabular}


Table I. (cont.)

\begin{tabular}{|c|c|c|c|c|c|c|c|}
\hline \multirow{2}{*}{$\begin{array}{l}\text { Sample } \\
\text { name }\end{array}$} & \multirow{2}{*}{ Location $^{2}$} & \multirow{2}{*}{ Country } & \multirow{2}{*}{$\begin{array}{l}\text { Collection } \\
\text { date }^{2}\end{array}$} & \multirow{2}{*}{$\begin{array}{l}\text { Population } \\
\text { ID }^{3}\end{array}$} & \multirow{2}{*}{$\begin{array}{l}\text { BAPS } \\
\text { Group }^{4}\end{array}$} & \multicolumn{2}{|c|}{ Accession number of } \\
\hline & & & & & & tef1 & ITS \\
\hline TG 1 & Nagybánya & Romania & 7 September 2011 & 4 & 12 & KC879207 & KC844351 \\
\hline TG 2 & Nagybánya & Romania & 7 September 2011 & 4 & 12 & KC879208 & KC844352 \\
\hline TG 4T & Nagybánya & Romania & 7 September 2011 & 4 & 12 & KC879209 & KC844353 \\
\hline VEVI 1 & Nagybánya & Romania & 7 September 2011 & 4 & 12 & KC879212 & KC844356 \\
\hline VEVI 2 & Nagybánya & Romania & 7 September 2011 & 4 & 12 & KC879213 & KC844357 \\
\hline TIS 3 & Tismana & Romania & 2 September 2012 & 4 & 2 & KC879210 & KC844354 \\
\hline TIS 5 & Tismana & Romania & 2 September 2012 & 4 & 2 & KC879211 & KC844355 \\
\hline PET 1 & Petrich & Bulgaria & 5 October 2011 & 5 & 14 & KC879196 & KC844337 \\
\hline PET 3 & Petrich & Bulgaria & 5 October 2011 & 5 & 14 & KC879197 & KC 844338 \\
\hline OSOJ 2 & Osoj & Macedonia & 4 October 2011 & 5 & 13 & KC879187 & KC844328 \\
\hline OSOJ 7 & Osoj & Macedonia & 4 October 2011 & 5 & 13 & & KC844329 \\
\hline RAD 1 & Radolishta & Macedonia & 5 October 2011 & 5 & 12 & KC879201 & KC844343 \\
\hline RAD 5 & Radolishta & Macedonia & 5 October 2011 & 5 & 12 & KC879202 & KC844344 \\
\hline TET 3 & Tetovo & Macedonia & 4 October 2011 & 5 & 12 & KC879205 & KC844349 \\
\hline TET 9 & Tetovo & Macedonia & 4 October 2011 & 5 & 12 & KC879206 & KC844350 \\
\hline VOL 1 & Volino & Macedonia & 4 October 2011 & 5 & 12 & KC879214 & KC844326 \\
\hline VOL 4 & Volino & Macedonia & 4 October 2011 & 5 & 12 & KC879215 & KC844327 \\
\hline VRUT 1 & Vrutok & Macedonia & 4 October 2011 & 5 & 12 & KC879216 & KC844358 \\
\hline VRUT 3 & Vrutok & Macedonia & 4 October 2011 & 5 & 12 & KC879217 & KC844359 \\
\hline ARK 14 & n.a. & Greece & n.a. & 6 & 15 & & KC844293 \\
\hline HOR $10 \mathrm{hpv}$ & n.a. & Greece & n.a. & 6 & 15 & & KC851945 \\
\hline KAV 5 hpv & n.a. & Greece & n.a. & 6 & 15 & & KC851944 \\
\hline ME48-1 & n.a. & Greece & n.a. & 6 & 15 & KC879181 & KC851948 \\
\hline ME48-2 & n.a. & Greece & n.a. & 6 & 15 & KC879182 & KC851949 \\
\hline P 73 & n.a. & Greece & n.a. & 6 & 15 & KC879190 & KC851943 \\
\hline P5-1 & n.a. & Greece & n.a. & 6 & 15 & KC879188 & KC851946 \\
\hline P5-2 & n.a. & Greece & n.a. & 6 & 15 & KC879189 & KC851947 \\
\hline PIR 1 & n.a. & Greece & n.a. & 6 & 15 & KC879200 & KC851942 \\
\hline
\end{tabular}


Table I. (cont.)

\begin{tabular}{lllllll}
\hline $\begin{array}{l}\text { Sample } \\
\text { name }^{1}\end{array}$ & Location & Country & $\begin{array}{l}\text { Collection } \\
\text { date }\end{array}$ & $\begin{array}{l}\text { Population } \\
\text { ID }^{3}\end{array}$ & $\begin{array}{l}\text { BAPS } \\
\text { Group }^{4} \text { tef1 }\end{array}$ & ITS \\
\hline C0006 & Alentejo & Portugal & n.a. & 7 & 16 & KC851938 \\
C0009 & Madeira & Portugal & n.a. & 7 & 16 & KC851940 \\
C0008 & Terceira & Portugal & n.a. & 7 & 16 & KC851939 \\
C0722 & Terceira & Portugal & n.a. & 7 & 16 & KC851941 \\
C0003 & Trás os & Portugal & n.a. & 7 & 16 & KC851937 \\
\hline
\end{tabular}

${ }^{1}$ Host of the isolates were Castanea sativa except the ones with a " $\mathrm{T}$ " ending

(BOB 2-2T, BOB 2-4T, TG 4T, FEL 1T, KOBA 4T). Those were isolated from Quercus petraea.

${ }^{2}$ n.a.: not available.

${ }^{3}$ Number of population: geographical locations are indicated in Fig. 1.

${ }^{4}$ BAPS Group: according to the results of the BAPS analysis.

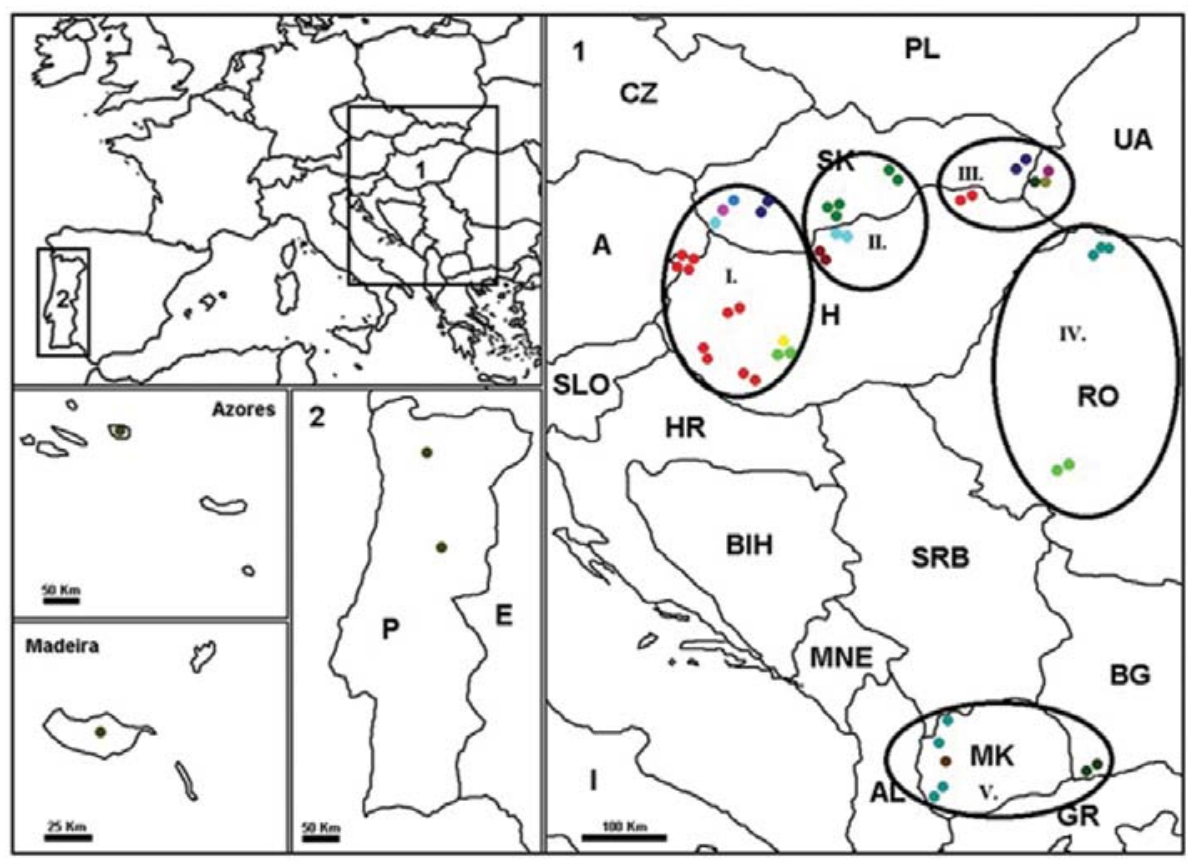

Figure 1. Geographical location of the Cryphonectria parasitica populations sampled in the Carpathian Basin and in Europe. Each isolate is represented by one dot. I-V indicates population numbers of the isolates (Table I). The colours of the dots correspond with the result of BAPS analysis 


\section{Culture morphology and growth}

Isolates were grown on PDA (40 $\mathrm{g} \mathrm{l}^{-1}$, Scharlab) in $90 \mathrm{~mm}$ diameter Petri dishes incubated at $25^{\circ} \mathrm{C}$ in the dark for one week. The cultures were then exposed to diffuse daylight at room temperature on the laboratory bench, and culture morphology was recorded once a week for a period of four weeks.

\section{DNA extraction}

For molecular works, the cultures were grown in $100 \mathrm{ml}$ of malt broth (MB, containing $2 \%$ malt extract, Scharlab) for 48 hours at room temperature in the dark on a rotary shaker $(125 \mathrm{rpm})$. Mycelium from each culture was transferred to $100 \mathrm{ml}$ Erlenmeyer flasks containing 50ml MB. The cultures were grown at room temperature for 48 hours in the dark on a rotary shaker (125 rpm). Mycelia were harvested by vacuum filtration. Total genomic DNA was extracted from freeze-dried mycelium and isolated using NucleoSpin Plant II (Macherey-Nagel, 740770) according to the protocol, followed the manufacturer's instructions. DNA concentrations were measured by NanoDrop (Thermo Scientific).

\section{Amplification and sequencing of ITS and tefl sequences}

Amplifications of $50 \mu \mathrm{l}$ PCR reaction containing $25 \mu \mathrm{l} 2 \times \mathrm{PCR}$ Master Mix (ImmoMix, Bioline, 25020), 40-40 pmol of each primer, 20-40 ng of genomic DNA and nuclease free water were run. SR6R and LR1 primer pair [42] (Integrated DNA Technologies, Inc.) were used to amplify the full length of ITS region, with the following amplification protocol: $3 \mathrm{~min}$ initial denaturing at $95^{\circ} \mathrm{C}$, followed by 5 cycles of $1 \mathrm{~min}$ at $95^{\circ} \mathrm{C}, 1 \mathrm{~min}$ annealing at $50{ }^{\circ} \mathrm{C}, 1 \mathrm{~min}$ at $72{ }^{\circ} \mathrm{C}$ and 25 cycles of $1 \mathrm{~min}$ at $90{ }^{\circ} \mathrm{C}, 1 \mathrm{~min}$ annealing at $50{ }^{\circ} \mathrm{C}, 1 \mathrm{~min}$ at $72{ }^{\circ} \mathrm{C}$ and $15 \mathrm{~min}$ final extension at $72^{\circ} \mathrm{C}$. The large intron of the tefl gene was amplified by the EF1-728F and EF1-986R primer pair [19] according to the previously described protocol with a temperature of $56{ }^{\circ} \mathrm{C}$ rather than $50{ }^{\circ} \mathrm{C}$. PCR was performed in a Primus (MWG Biotech) thermocycler. Amplification products were subjected to electrophoresis in a $0.7 \%$ agarose gel containing EtBr and visualized by UV illumination. The PCR products were purified by using NucleoSpin Gel and PCR Clean-up (Macherey-Nagel, 740609). Purified amplification products were sequenced by MWG Biotech Company in Germany. 


\section{Data analysis}

The DNA sequences obtained were aligned first with ClustalX [43] automatically then manually checked for ambiguities and adjusted when necessary using GeneDoc [44]. Single gaps were treated as missing data and multistate characters as uncertain. In the phylogenetic analyses, tefl and ITS fragments of other $C$. parasitica isolates downloaded from GenBank (NCBI) were also included. Parsimony analyses [45-47] were performed using PAUP 4.0 [48] and consisted of heuristic searches with 1000 random addition sequences and tree bisection-reconnection (TBR) branch swapping. All characters were equally weighted and alignment gaps were treated as missing data. The stability of clades was assessed with 1000 bootstrap replications. Phylogenetic trees were drawn by TreeView [49].

\section{Microsatellite amplification and analysis}

In this study, six microsatellites (Table II) were selected as previously described by Breuillin et al. [10] and Kubisiak et al. [39]. Amplifications were carried out in $50 \mu \mathrm{l}$ reactions, which contained $25 \mu \mathrm{l}$ 2X PCR Master Mix (ImmoMix, Bioline, 25020), 40-40 pmol each primer, 20-40 ng of genomic DNA and nuclease free water were run out. Microsatellites were amplified in a Primus (MWG Biotech) thermocycler using the following thermal profile: 3 min initial

Table II. List of microsatellite loci with primer sequences and annealing temperatures used for the amplification

\begin{tabular}{lll}
\hline Locus & Primers & Annealing temperature \\
\hline CpSI085 & $\begin{array}{l}\text { Forward 5' AGGCCTGCTTCTTTTTGGAT 3' } \\
\text { Reverse 5' CGGGTCTATATGGTGGCTTC 3' }\end{array}$ & $55^{\circ} \mathrm{C}$ \\
& $\begin{array}{l}\text { Forward 5' GCTCCGAGGACTTTGATGAG 3' } \\
\text { CpSI102 }\end{array}$ & $55^{\circ} \mathrm{C}$ \\
& Reverse 5' TCATCACCACCAACACCATT 3' & \\
CpSI108 & Forward 5' CGGAACTACCTGCTCTTTGC 3' & $56{ }^{\circ} \mathrm{C}$ \\
& Reverse 5' GCGATCCGCATTCCTGTAT 3' & \\
CPG6 & $\begin{array}{l}\text { Forward 5' ATCATCACGACGCAATGGTA 3' } \\
\text { Reverse 5' TCCGGGCATTCAGCAMAT 3' }\end{array}$ & \\
CPE5 & $\begin{array}{l}\text { Forward 5' TGTCAACAACGGTCAACACC 3' } \\
\text { Reverse 5' CGGAGAGGAGAACTCTGAGAC 3' }\end{array}$ & $56{ }^{\circ} \mathrm{C}$ \\
CpSI014 & $\begin{array}{l}\text { Forward 5' TCGGAGGCTTTATTGTCGTT 3' } \\
\text { Reverse 5' TGGGTGTATTTGCTCGGTAA 3' }\end{array}$ & \\
\hline
\end{tabular}


denaturing at $95{ }^{\circ} \mathrm{C}$, followed by 5 cycles of 1 min at $95{ }^{\circ} \mathrm{C}, 1 \mathrm{~min}$ annealing (Table II) $1 \mathrm{~min}$ at $53-56{ }^{\circ} \mathrm{C}$ (depending on the primer sequences) and 25 cycles of $1 \mathrm{~min}$ at $90{ }^{\circ} \mathrm{C}, 1 \mathrm{~min}$ annealing at $53-56{ }^{\circ} \mathrm{C}, 1 \mathrm{~min}$ at $72{ }^{\circ} \mathrm{C}$ and $15 \mathrm{~min}$ final extension at $72^{\circ} \mathrm{C}$. Fragment analyses were completed by Origins electrophoresis system produced by Elchrom Scientific AG (Switzerland). Each PCR product was analyzed on Spreadex EL 500 Gel (Elchrom Scientific AG, Switzerland), run at $55^{\circ} \mathrm{C}$ for $240 \mathrm{~min}$ in a $1 \mathrm{X}$ TAE buffer. The gel was stained with EtBr (Sigma, USA) for $45 \mathrm{~min}$, and photographed under UV light $(\mathrm{k}=250 \mathrm{~nm}) \mathrm{using}$ Bio-Rad gel documentation system.

\section{Microsatellite fragment length analysis}

The Popgene version 1.31 software [50] was used to compute basic population parameters such as "observed number of alleles" $\left(\mathrm{n}_{\mathrm{a}}\right)$, "effective number of alleles" $\left(\mathrm{n}_{\mathrm{e}}\right)$, and "Nei's gene diversity" (h) in the total sample and in each population. Nei's [51] genetic identity is the normalized identity of genes between two populations and varies between 0 (the compared populations are different), and 1 (the compared populations are identical). Multilocus $1.3 \mathrm{~b}$ was used to calculate the number of different multilocus genotypes (MLG) and the standardized version of the index of association $r_{D}$ [52]. The $r_{D}$ index was calculated to test for genetic recombination. This index is a measure of multilocus linkage disequilibrium, which gives information on whether two different individuals sharing the same allele at one locus are more likely to share an allele at another locus. The null hypothesis of complete panmixia $\left(r_{D}=0\right)$ was tested by comparing the observed data set to 100 randomized data sets in which infinite recombination was simulated upon randomly shuffling the alleles among individuals, independently for each locus.

Population differentiation was tested by comparing allele frequencies among the six populations using Weir and Cockerham's $\theta\left(\mathrm{F}_{\mathrm{st}}\right)$ value [53]. The $\theta$-value was estimated under the null hypothesis of non-differentiation among subpopulations, when $\theta=0$. Statistical analysis was performed by comparing the calculated $\theta$-values to those of data sets in which the isolates have been randomized across populations 10,000 times using the Multilocus 1.3b (Multi Locus Sequence Typing) [52]. Gene flow $\left(\mathrm{N}_{\mathrm{m}}\right.$ - equivalent to the number of migrants per generation) was determined using the equation $\mathrm{N}_{\mathrm{m}}=0.5(1-\theta) / \theta[54]$.

The structure of the populations were analyzed with BAPS 6.16 (Bayesian Analysis of Population Structure) program (http:/www.helsinki.fi/bsg/software/ BAPS/), applying Bayesian approach. This program was used to determine the most probable number of groups of $C$. parasitica isolates, based on posterior 
probability, and to define the group for each isolate $[55,56]$. The most probable cluster number was tested in 10 repetitions between 1 and 50 values. The allele frequencies of the isolates were tested on the defined cluster number with 100 repetitions.

\section{Results}

Phylogenetic analyses of tef1 and ITS sequences

PCR amplifications resulted in single fragments for both tef1 ( $\sim 350 \mathrm{bp})$ and ITS region ( $\sim 560 \mathrm{bp})$. No size variation was observed among the amplified tef1 and ITS fragments of the different isolates. The parsimony analysis of the ITS fragment revealed 299 constant sites, with 172 parsimony-informative sites, and 76 parsimony-uninformative sites among all isolates. The $C$. parasitica was clearly separated from other species in the Cryphonectriaceae family and the isolates were grouped in several clades which indicated the high variability in the ITS region (Fig. 2). However, no correlation was found between the clades and the geographical regions. The isolates of the same regions were not grouped in the same clade. Moreover, isolates with different geographical origins were randomly mixed in the same clade (Fig. 2, Table I). The ITS sequences downloaded from the GenBank were also found in different clades, sometimes together with isolates from Hungary. The robustness of the tree was supported by relatively high bootstrap values. Tef1 sequences were edited to $320 \mathrm{bp}$ for the alignment. The tef 1 sequences of all studied isolates proved to be perfectly identical, including the two tef1 sequences from South Africa (AY308953, AY308954). No sequence variation was found in the tefl sequences of $C$. parasitica isolates collected from Europe.

\section{Microsatellite analysis}

Microsatellite fragment length analysis included 82 samples collected from the Carpathian Basin, especially from southern Romania, Macedonia and Bulgaria. Further 14 isolates were provided by different European laboratories. Six microsatellites of a total of 96 isolates were amplified and their lengths were determined. Seven different populations with similar geographical origin were grouped together for further analysis. Isolates from the Carpathian Basin were divided into four populations: (I) Western, (II) Central-Northern, (III) NorthEastern, and (IV) Eastern (Fig. 1). All populations contained more than one mul- 


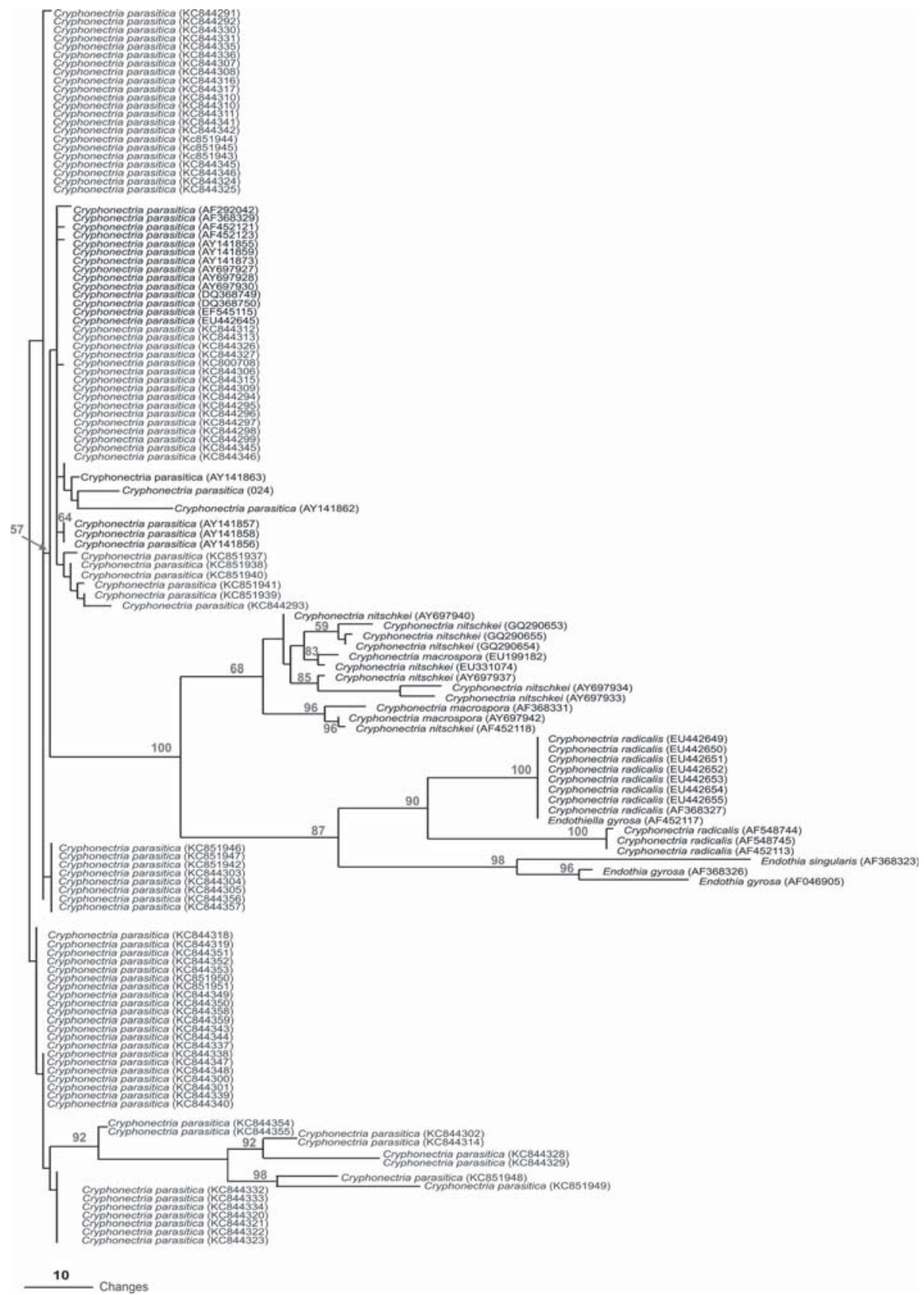

Figure 2. One of the most parsimonious trees of ITS sequences of Cryphonectria parasitica isolates 
Table III. Genetic diversity indexes of Cryphonectria parasitica populations

\begin{tabular}{|c|c|c|c|c|c|c|c|c|}
\hline Population $^{\mathrm{a}}$ & $\mathrm{n}^{\mathrm{b}}$ & $\mathrm{n}_{\mathrm{a}}^{\mathrm{c}}$ & $n_{e}^{d}$ & $\mathrm{~h}^{\mathrm{e}}$ & $\begin{array}{c}\text { No. } \\
\text { of distinct } \\
\text { MLG }^{\mathrm{f}}\end{array}$ & $\begin{array}{l}\text { Max. no. } \\
\text { of repeated } \\
\text { MLG }^{\mathrm{g}}\end{array}$ & $\begin{array}{c}\text { Genotypic } \\
\text { diversity }\end{array}$ & $r_{D}{ }^{h}$ \\
\hline 1 & 28 & $\begin{array}{l}4.00 \\
(1.55)\end{array}$ & $\begin{array}{l}2.38 \\
(0.88)\end{array}$ & $\begin{array}{l}0.52 \\
(0.20)\end{array}$ & 23 & 3 & 0.984 & $0.073^{* *}$ \\
\hline 2 & 16 & $\begin{array}{l}3.33 \\
(1.63)\end{array}$ & $\begin{array}{l}2.58 \\
(1.40)\end{array}$ & $\begin{array}{l}0.49 \\
(0.29)\end{array}$ & 13 & 2 & 0.975 & $0.134 * *$ \\
\hline 3 & 14 & $\begin{array}{l}3.50 \\
(0.84)\end{array}$ & $\begin{array}{l}2.92 \\
(0.94)\end{array}$ & $\begin{array}{l}0.61 \\
(0.19)\end{array}$ & 8 & 3 & 0.923 & $0.130 *$ \\
\hline 4 & 11 & $\begin{array}{l}3.00 \\
(0.63)\end{array}$ & $\begin{array}{l}2.29 \\
(0.38)\end{array}$ & $\begin{array}{l}0.55 \\
(0.07)\end{array}$ & 9 & 2 & 0.963 & $0.085^{*}$ \\
\hline 5 & 12 & $\begin{array}{l}2.66 \\
(0.81)\end{array}$ & $\begin{array}{l}2.00 \\
(0.83)\end{array}$ & $\begin{array}{l}0.44 \\
(0.17)\end{array}$ & 9 & 2 & 0.954 & 0.067 \\
\hline 6 & 9 & $\begin{array}{l}2.00 \\
(0.63)\end{array}$ & $\begin{array}{l}1.50 \\
(0.19)\end{array}$ & $\begin{array}{l}0.29 \\
(0.20)\end{array}$ & 7 & 2 & 0.944 & 0 \\
\hline 7 & 5 & $\begin{array}{l}1.50 \\
(0.83)\end{array}$ & $\begin{array}{l}1.37 \\
(0.58)\end{array}$ & $\begin{array}{l}0.17 \\
(0.27)\end{array}$ & 4 & 2 & 0.900 & 0 \\
\hline Total & 95 & $\begin{array}{l}5.67 \\
(1.63)\end{array}$ & $\begin{array}{l}3.25 \\
(0.83)\end{array}$ & $\begin{array}{l}0.67 \\
(0.12)\end{array}$ & 71 & 2 & 0.999 & $0.038^{* *}$ \\
\hline
\end{tabular}

${ }^{\text {a }}$ Population numbers according to Fig. 1.

${ }^{\text {bSample size. }}$

${ }^{\mathrm{c}}$ Observed number of alleles.

${ }^{\mathrm{d}}$ Effective number of alleles.

'Nei's gene diversity.

${ }^{\mathrm{f}}$ Number of distinct multilocus genotypes.

${ }^{\mathrm{g}}$ Maximum number of repeated multilocus genotypes.

${ }^{\mathrm{h}}$ Standardized index of association (clone corrected).

Standard deviation between brackets.

$* \mathrm{p}<0.01$

$* * \mathrm{p}<0.001$

tilocus genotype (MLG) (Table III). The studied alleles proved to be suitable to measure genetic diversity among the isolates since the genetic diversity did not change significantly including more than three alleles in the analysis (data not shown). Fragment size analysis of the six microsatellite loci produced 71 haplotypes among 95 isolates (Table III). The effective number of alleles $\left(\mathrm{n}_{\mathrm{e}}: 2.00\right.$ 2.58) and Nei's gene diversity (h: $0.44-0.61)$ were similar in the populations with more than 10 isolates (Table III).

The genotypic diversity calculated both for the total samples (0.999) and for the individual populations (0.900-0.984) was similar, independently of the population size (Table III). 
Table IV. F statistics of Cryphonectria parasitica populations. Weir and Cockerham's $\theta$ ( $\left.\mathrm{F}_{\mathrm{st}}\right)$ (rows), and $\mathrm{N}_{\mathrm{m}}$ (columns) were calculated with Multilocus $1.3 \mathrm{~b} ; \mathrm{N}_{\mathrm{m}}=0.5(1-\theta) / \theta$.

Light grey background indicates moderate $(\theta: 0.05-0.15)$, dark grey big $(\theta: 0.15-0.25)$, black very big $(\theta:>0.25)$ differences between populations

\begin{tabular}{|c|c|c|c|c|c|c|c|}
\hline$\gamma^{\theta}$ & $\begin{array}{l}1 . \\
\text { population }\end{array}$ & $\begin{array}{l}2 . \\
\text { population }\end{array}$ & $\begin{array}{l}3 . \\
\text { population }\end{array}$ & $\begin{array}{l}4 . \\
\text { population }\end{array}$ & $\begin{array}{l}5 . \\
\text { population }\end{array}$ & $\begin{array}{l}6 . \\
\text { population }\end{array}$ & $\begin{array}{l}7 . \\
\text { population }\end{array}$ \\
\hline 1. population & & $0.242 * *$ & $0.124^{* *}$ & $0.207 *$ & $0.293^{*}$ & $0.282^{* *}$ & $0.387^{* *}$ \\
\hline 2. population & 0.156 & & $0.167^{* *}$ & $0.263^{* *}$ & $0.403^{* *}$ & 0.238 & 0.341 \\
\hline 3. population & 0.353 & 0.249 & & 0.130 & 0.263 & 0.185 & 0.350 \\
\hline 4. population & 0.191 & 0.140 & 0.334 & & 0.067 & 0.207 & 0.444 \\
\hline 5. population & 0.120 & 0.074 & 0.140 & 0.696 & & 0.336 & 0.561 \\
\hline 6. population & 0.127 & 0.160 & 0.220 & 0.191 & 0.090 & & 0.619 \\
\hline 7. population & 0.028 & 0.096 & 0.092 & 0.062 & 0.039 & 0.030 & \\
\hline
\end{tabular}

$* \mathrm{p}<0.01$

$* * \mathrm{p}<0.001$

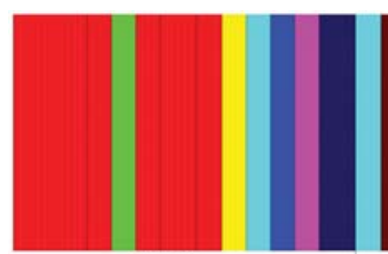

Pop 1

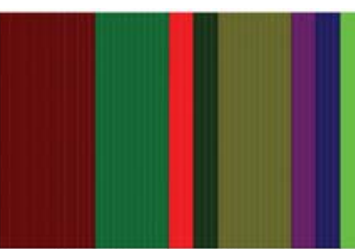

Pop 2

Pop 3

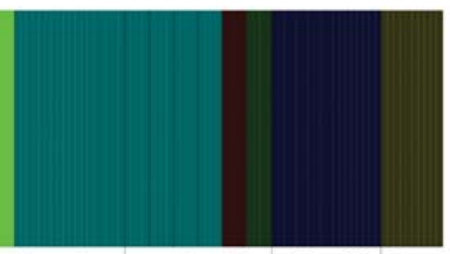

Pop 4

\begin{tabular}{l|l|l} 
Pop 5 & Pop 6 Pop 7
\end{tabular}

Figure 3. Bayesian assignment of individuals into different clusters assigned by BAPS program (http://www.helsinki.fi/bsg/software/BAPS/). The bar-plot with different colours shows the assignment of individuals into different clusters

The clone-corrected standardized index of association $\left(\mathrm{r}_{\mathrm{D}}\right)$, computed on the total sample was significantly different from zero $\left(r_{D}=0.038, p<0.01\right.$, Table III), indicating genetic differentiation between populations. The estimate of linkage disequilibrium varied between 0.073 and 0.134 at $p<0.01$. This may suggest the possible differentiation within the populations (Table III).

The F statistics (Weir and Cockerham's $\theta$ ), and gene flow ( $\mathrm{N}_{\mathrm{m}}$ values) indicated very high $(\theta:>0.25)$, high $(\theta: 0.15-0.25)$ and moderate $(\theta: 0.05-0.15)$ differentiation between populations with significant differences in populations with many isolates (Table IV). C. parasitica isolates from Portugal (population 7) markedly differed from all the other isolates from the Balkans and Central Europe. However, only a moderate difference $(\theta: 0.124-0.167)$ could be observed between populations from the northern part (populations 2 and 3 ) or eastern part (populations 3 and 4) of the Carpathian Basin. Similar moderate differences were 
also calculated between geographically distinct populations (populations 4 and 6 , Fig. 1).

The BAPS analysis created 16 groups with 0.9131 probability (Fig. 3) based on the microsatellite diversity of the samples originated from twenty-three different sampling sites. Samples from Portugal and Greece markedly separated from other isolates. However, C. parasitica samples from the Carpathian Basin formed several groups, but there was no connection between the groups and the geographical regions (Fig. 1). Occasionally samples from remote geographical origin grouped together (in populations I and III, I and IV, IV and V). However, samples from different hosts (Castanea sativa and Quercus petraea) always grouped together on the same sampling sites (Table I and Figs 1 and 3).

\section{Discussion}

The nuclear ribosomal DNA has long been used as a potential genetic marker for phylogenetic studies [20, 57]. In many fungal taxonomy studies, the ITS region was suitable for resolving relationships at genus and species level [58-64]. In this study, ITS sequences were used to estimate the phylogenetic relationships at intraspecies level among $C$. parasitica isolates collected from different geographical regions of Europe. The ITS region proved to be highly polymorphic but this kind of variability did not reflect the geographical regions of the isolates. The translation elongation factor coding gene proved to be a useful gene to resolve phylogenetic relationships at species level, as well as in deeper divergences in many fungi $[17,19,65]$. However, in this study, the tefl sequences were identical in all isolates supporting that these sequences remained conservative within $C$. parasitica species. The tefl sequence was not suitable for investigating phylogenetic relationships within $C$. parasitica isolates collected from different regions of Europe.

The diversity of $C$. parasitica populations has been investigated extensively. It was reported to be higher in its native range, in eastern Asia, than in recently established populations in Europe and North America [66]. High vegetative compatibility diversity was found in northern Italy, where chestnut blight was first reported in Europe in 1938 [67], moreover in the neighbouring southern part of Switzerland [68], in Bosnia-Herzegovina [69] and in the southern part of France [70]. However lower diversity was observed in the newly infected areas e.g. in Germany [71], Portugal and northern Switzerland [8]. The diversity of the C. parasitica populations in the Carpathian Basin populations $(\mathrm{h}=0.49-0.61)$ was higher, than calculated for the populations in North America $\left(\mathrm{H}_{\mathrm{e}}=0.41\right)$, but lower than in Asia $\left(\mathrm{H}_{\mathrm{e}}=0.73\right)$ [72]. Microsatellite haplotypes were found to be 
highly diverse in Hungary [7], France [10], Slovenia and Croatia [73] which corresponds well with the relatively high diversity of vegetative compatibility type in that area. This may have resulted from the multiple introductions from diverse origins of the European populations, close to the first site of observation in Northern Italy [66]. We calculated moderate differences between geographically distinct populations of Romania and Greece. Moreover the BAPS analysis occasionally grouped together samples from remote geographical origin, suggesting human assistance in the introduction of new $C$. parasitica haplotypes from distinct areas (e.g. by infected propagation materials).

\section{Acknowledgement}

E. Sándor was supported by the "Research Grant" of the University of Debrecen.

\section{Conflict of Interest}

The authors certify that they have NO affiliations with or involvement in any organization or entity with any financial interest (such as honoraria; educational grants; participation in speakers' bureaus; membership, employment, consultancies, stock ownership, or other equity interest; and expert testimony or patent-licensing arrangements), or non-financial interest (such as personal or professional relationships, affiliations, knowledge or beliefs) in the subject matter or materials discussed in this manuscript.

\section{References}

1. Anagnostakis, S. L.: Chestnut blight: The classical problem of an introduced pathogen. Mycologia 79, 23-37 (1987).

2. Braghi, A.: Il cranco del castagno causato da Endothia parasitica. Ital Agric 7, 406-412 (1946).

3. Donaubauer, E.: Unterschungen über den die variation der Krankheitsanfälligkeit verschiedener Pappeln. Mitt. FBVA. Brunn. 1964, pp. 70-120.

4. Körtvély, A.: A gesztenye endotiás kéregelhalása. Növényvédelem 6, 358-361 (1969).

5. Juhásová, G.: A summary of knowledge of fungal diseases of Spanish chestnut in Slovakia. Forestry 38, 449-460 (1976).

6. Florea, S., Popa, I.: Diseases of edible chestnut reported in the fruit growing area of Baia Mare. In Cercetarea ştiinţifică in slujba producţiei pomicole1969-1989, Bucureşti, Romania, 1989, pp. 365-372. 
7. Radócz, L.: Study of subpopulations of the chestnut blight (Cryphonectria parasitica) fungus in the Carpathian-Basin. For Snow Landsc Res 76, 368-372 (2001).

8. Hoegger, P. J., Rigling, D., Holdenrieder, O., Heiniger, U.: Genetic structure of newly established populations of Cryphonectria parasitica. Mycol Res 104, 1108-1116 (2000).

9. Marra, R. E., Cortesi, P., Bissegger, M., Milgroom, M. G.: Mixed mating in natural populations of the chestnut blight fungus Cryphonectria parastica. Heredity 93, 189-195 (2004).

10. Breuillin, F., Dutech, C., Robin, C.: Genetic diversity of the chestnut blight fungus Cryphonectria parasitica in four French populations assessed by microsatellite markers. Mycol Res 110, 288-296 (2006).

11. Milgroom, M. G., Sotirovski, K., Spica, D., Davis, J. E., Brewer, M. T., Milev, M., Cortesi, P.: Clonal population structure of the chestnut blight fungus in expanding ranges in southeastern Europe. Mol Ecol 17, 4446-4458 (2008).

12. Prospero, S., Rigling, D.: Invasion genetics of the chestnut blight fungus Cryphonectria parasitica in Switzerland. Phytopathology 102, 73-82 (2012).

13. Prospero, S., Lutz, A., Tavadze, B. A., Supatashvili, B., Rigling, D.: Discovery of a new gene pool and a high genetic diversity of the chestnut blight fungus Cryphonectria parasitica in Caucasian Georgia. Infect Genet Evol 20, 131-139 (2013).

14. Jezic, M., Krstin, L., Rigling, D., Curkovic-Perica, M.: High diversity in populations of the introduced plant pathogen, Cryphonectria parasitica, due to encounters between genetically divergent genotypes. Mol Ecol 21, 87-99 (2012).

15. Peters, F. S., Bußkamp, J., Prospero, S., Rigling, D., Metzler, B.: Genetic diversification of the chestnut blight fungus Cryphonectria parasitica and its associated hypovirus in Germany. Fungal Biol 118, 193-210 (2014).

16. Moldave, K.: Eukaryotic protein synthesis. Annu Rev Biochem 54, 1109-1149 (1985).

17. Roger, A. J., Sandblom, O., Doolittle, W. F., Philippe, H.: An evaluation of elongation factor $1 \alpha$ as a phylogenetic marker for eukaryotes. Mol Biol Evol 16, 218-233 (1999).

18. Baldauf, S. L., Doolittle, W. F.: Origin and evolution of slime molds (Mycetozoa). Proc Natl Acad Sci U S A 94, 12007-12012 (1997).

19. Druzhinina, I., Kubicek, C. P.: Species concepts and biodiversity in Trichoderma and Hypocrea: from aggregate species to species cluster? Journal of Zhejiang University Science 6, 100-112 (2005).

20. Avise, J. C.: Molecular markers, natural history, and evolution. 2nd Edition. Sinauer Associates, Sunderland, Massachusetts, 2004, pp. 660-684.

21. Gerbi, S. A.: Evolution of ribosomal DNA. In Macintyre, R. J. (ed.): Molecular Evolutionary Genetics. Plenum, New York, 1985, pp. 419-517.

22. Hillis, D. M., Dixon, M. T.: Ribosomal DNA: Molecular evolution and phylogenetic inference. Q Rev Biol 66, 411-453 (1991).

23. Baldwin, B. G.: Phylogenetic utility of the internal transcribed spacers of nuclear ribosomal DNA in plants: An example from the Compositae. Mol Phylogenet Evol 1, 3-16 (1992).

24. Schlötterer, C., Hauser, M., von Haeseler, A., Tautz, D.: Comparative evolutionary analysis of rDNA ITS regions in Drosophila. Mol Biol Evol 11, 513-522 (1994).

25. Mai, J. C., Coleman, A. W.: The internal transcribed spacer 2 exhibits a common secondary structure in green algae and flowering plants. J Mol Evol 44, 258-271 (1997). 
26. Weekers, P. H. H., Jonckheere, F. J., de, Dumont, H. J.: Phylogenetic relationships inferred from ribosomal ITS sequences and biogeographic patterns in representative of the genus Calopteryx (Insecta: Odonata) of the West Mediterranean and adjacent west European zone. Mol Phylogenet Evol 20, 89-99 (2001).

27. Oliverio, M., Cervelli, M., Mariottini, P.: ITS2 rRNA evolution and its congruence with the phylogeny of muricid neogastropods (Caenogastropoda, Muricoidea). Mol Phylogenet Evol 25, 63-69 (2002).

28. Chen, C. A., Wallace, C. C., Wolstenholme, J.: Analysis of mitochondrial 12S RNA gene supports a two-clade hypothesis of the evolutionary history of scleractinian corals. Mol Phylogenet Evol 23, 137-149 (2002).

29. Chen, C. A., Yu, J. K., Wei, N. W.: Strategies for amplification by polymerase chain reaction of the complete sequence of nuclear large subunit ribosomal RNA-encoding gene in corals. Mar Biotech 6, 558-570 (2000).

30. Braganca, H., Rigling, D., Diogo, E., Capelo, J., Phillips, A., Tenreiro, R.: Cryphonectria natarciae: A new species in the Crpyhonectria-Endothia complex and diagnostic molecular markers based on microsatellite-primed PCR. Fungal Biol 115, 852-861 (2011).

31. Gryzenhout, M., Wingfield, B., Wingfield, M.: New taxonomic concepts for the important forest pathogen Cryphonectria parasitica and related fungi. FEMS Microbiol Lett 258, 161-172 (2006).

32. Jarne, P., Lagoda, P. J. L.: Microsatellites, from molecules to populations and back. Trends Ecol Evol. 11, 424-429 (1996).

33. Tautz, D.: Notes on the definition and nomenclature of tandemly repetitive DNA sequences. In Pena, S. D. J., Chakraborty, R., Epplen, J. T., Jeffreys, A. J. (eds): DNA Fingerprinting: State of Science. Birkhauser, Basel, 1993, pp. 21-28.

34. Lai, Y., Sun, F.: The relationship between microsatellite slippage mutation rate and the number of repeat units. Mol Biol Evol 20, 2123-2131 (2003).

35. Levinson, G., Gutman, G. A.: Slipped-strand mispairing: A major mechanism for DNA sequence evolution. Mol Evol 4, 203-221 (1987).

36. Selkoe, K. A., Toonen, R. J.: Microsatellites for ecologists: A practical guide to using and evaluating microsatellite markers. Ecol Lett 9, 615-629 (2006).

37. Weber, J. L., Wong, C.: Mutation of human short tandem repeats. Hum Mol Genet 2, 1123-1128 (1993).

38. Schug, M. D., Mackay, T. F. C., Aquadro, C. F.: Low mutation rates of microsatellite loci in Drosophila melanogaster. Nature Genet 15, 99-102 (1997).

39. Kubisiak, T. L., Dutech, C., Milgroom, M. G.: Fifty-three polymorphic microsatellite loci in the chestnut blight fungus, Cryphonectria parasitica. Mol Ecol Notes 7, 428432 (2007).

40. Milgroom, M. G., Lipari, S. E., Powell, W. A.: DNA fingerprinting and analysis of population-structure in the Chestnut blight fungus, Cryphonectria parasitica. Genetics 131, 297-306 (1992).

41. Milgroom, M. G., Wang, K. R., Zhou, Y., Lipari, S. E., Kaneko, S.: Intercontinental population structure of the chestnut blight fungus, Cryphonectria parasitica. Mycologia 88, 179-190 (1996).

42. Vilgalys, R., Hester, M.: Rapid genetic identification and mapping of enzymatically amplified ribosomal DNA from several Cryptococcus species. J Bacteriol 20, 4238-4246 (1990). 
43. Thompson, J. D., Gibson, T. J., Plewniak, F., Jeanmougin, F., Higgins, D. G.: The ClustalX windows interface: Flexible strategies for multiple sequence alignment aided by quality analysis tools. Nucleic Acids Res 24, 4876-4882 (1997).

44. Nicholas, K. B., Nicholas, Jr. H. B., Deerfield, D. W. I.: GeneDoc: Analysis and visualization of genetic variation. Embnew News 4, 14 (1997).

45. Kluge, A. G., Farris, J. S.: Quantitative phyletics and the evolution of anurans. Syst Zool 18, 1-32 (1969).

46. Farris, J. S.: Estimating phylogenetic trees from distances matrixes. Am Nat 106, 645668 (1970).

47. Fitch, W. M.: Toward defining the course of evolution: Minimum change for a specific tree topology. Syst Zool 20, 406-416 (1971).

48. Swofford, D. L.: PAUP*: Phylogenetic Analysis Using Parsimony (*and Other Methods), Version 4b10. Sinauer Associates, Sunderland, MA, 2002.

49. Page, R. D. M.: TREEVIEW: An application to display phylogenetic trees on personal computers. Comput Appl Biosci 12, 357-358 (1996).

50. Yeh, F. C., Boyle, T.: Popgene: Microsoft Window-Based Freeware for Population Genetic Analysis. Version 1.31. Alberta, Canada: University of Alberta; http://www.ualberta.ca/ $\sim$ fyeh/popgene download.html, 1999.

51. Nei, M.: Genetic distance between populations. Amer Nat 106, 283-292 (1972).

52. Agapow, P. M., Burt, A.: Indices of multilocus linkage disequilibrium. Mol Ecol Not 1, 101-102 (2001).

53. Weir, B. S., Cockerham, C. C.: Estimating F-statistics for the analysis of population structure. Evolution 38, 1358-1370 (1984).

54. McDermott, J. M., McDonald, B. A.: Gene flow in plant pathosystems. Annu Rev Phytopathol 31, 353-373 (1993).

55. Corander, J., Waldmann, P., Sillanpää M. J.: Bayesian analysis of genetic differentiation between populations. Genetics 163, 367-374 (2003).

56. Tang, F., Barbacioru, C., Wang, Y., Nordman, E., Lee, C., Xu, N., Wang, X., Bodeau, J., Tuch, B. B., Siddiqui, A., Lao, K., Surani, M. A.: mRNA-Seq whole-transcriptome analysis of a single cell. Nat Methods 6, 377-382 (2009).

57. White, T. J., Bruns, T., Lee, S., Taylor, J.: Amplification and direct sequencing of fungal ribosomal RNA genes for phylogenetics. In Innis, M. A., Gelfand, D. H., Sninsky, J. J., White, T. J. (eds): PCR Protocols. A Guide to Methods and Applications. Academic Press, Inc., New York, 1990, pp. 315-322.

58. Gottlieb, A. M., Lichtwardt, R. W.: Molecular variation within and among species of Harpellales. Mycologia 93, 66-81 (2001).

59. Nugent, K. G., Saville, B. J.: Forensic analysis of hallucinogenic fungi: A DNA-based approach. Forensic Sci Int 140, 147-157 (2004).

60. Yli-Mattila, T., Mach, R. L., Alekhina, I. A., Bulat, S. A., Koskinen, S., KullnigGradinger, C. M., Kubicek, C. P., Klemsdal, S. S.: Phylogenetic relationships of Fusarium langsethiae to Fusarium poae and Fusarium sporotrichioides as inferred by IGS, ITS, $\beta$-tubulin sequences and UP-PCR hybridization analysis. Int J Food Microbiol 95, 267-285 (2004).

61. Voglmayr, H., Yule, C. M.: Polyancora globosa gen. sp. nov., an aeroaquatic fungus from Malaysian peat swamp forests. Mycol Res 110, 1242-1252 (2006). 
62. Morocko, I., Fatehi, J.: Molecular characterization of strawberry pathogen Gnomonia fragariae and its genetic relatedness to other Gnomonia species and members of Diaporthales. Mycol Res 111, 603-614 (2007).

63. Padamsee, M., Matheny, P. B., Dentinger, B. T. M., McLaughlin, D.: The mushroom family Psathyrellaceae: Evidence for large-scalepolyphyly of the genus Psathyrella. Mol Phylogenet Evol 46, 415-429 (2008).

64. Takamatsu, S., Hirata, T., Sato, Y., Nomura, Y.: Phylogenetic relationships of Microsphaera and Erysiphe section Erysiphe (powdery mildews) inferred from the rDNA ITS sequences. Mycoscience 40, 259-268 (1999).

65. Irinyi, L., Kövics, G. J., Sándor, E.: Taxonomic re-evaluation of Phoma-like soybean pathogenic fungi. Mycol Res 113, 249-260 (2009).

66. Liu, Y. C., Milgroom, M. G.: High diversity of vegetative compatibility types in Cryphonectria parasitica in Japan and China. Mycologia, 99, 279-284 (2007).

67. Cortesi, P., Milgroom, M. G., Bisiach, M.: Distribution and diversity of vegetative compatibility in subpopulations of Cryphonectria parasitica in Italy. Mycol Res 100, 10871093 (1996).

68. Heiniger, U., Rigling, D.: Biological control of chestnut blight in Europe. Annu. Rev. Phytopathol 32, 581-599 (1994).

69. Trestic, T., Uscuplic, M., Colinas, C., Rolland, G., Giraud, A., Robin, C.: Vegetative compatibility type diversity of Cryphonectria parasitica populations in Bosnia-Herzegovina, Spain and France. For Snow Landsc Res 76, 391-396 (2001).

70. Robin, C., Heiniger, U.: Chestnut blight in Europe: Diversity of Cryphonectria parasitica, hypovirulence and biocontrol. For Snow Landsc Res 76, 361-367 (2001).

71. Seemann, D., Bouffier, V., Kehr, R., Wulf, A., Schröder, T., Unger, J.: Die Ess - kastanie (Castanea sativa Mill.) in Deutschland und ihre Gefährdung durch den Kastanienrindenkrebs (Cryphonectria parasitica [Murr.] Barr). Nachr.bl. Dtsch. Pflanzen - schutzd. 53, 49-60 (2001).

72. Dutech, C., Barrès, B., Bridier, J., Robin, C., Milgroom, M. G., Ravigné, V.: The chestnut blight fungus world tour: Successive introduction events from diverse origins in an invasive plant fungal pathogen. Mol Ecol 21, 3931-3946 (2012).

73. Jezic, M., Krstin, L., Rigling, D., Curkovic-Perica, M.: High diversity in populations of the introduced plant pathogen, Cryphonectria parasitica, due to encounters between genetically divergent genotypes. Mol Ecol 21, 87-99 (2012). 